\title{
Response of alternate bearing of "Badamy sefid" Pistachio cultivar to foliar application of some macro and micro elements
}

\author{
Davarynejad, G. ${ }^{1}$ \& Davarynejad, E. ${ }^{2}$ \\ ${ }^{1}$ Department of Horticultural Science, College of Agriculture, Ferdowsi University of Mashhad, \\ Iran. P.O.Box $91775-1163$ \\ ${ }^{2}$ Institute of Biological Production Systems, Leibniz University of Hannover, Germany
}

\begin{abstract}
Summary: Response of "Badamy sefid" Pistachio trees to spraying of fertilizer was studied over two years (2006-2007). The boron and zinc fertilizer were used just on swelling time of female flower bud in compare to no fertilization (control). Also nutritional solution combined of nitrogen (400 ppm), phosphorus $\left(\mathrm{P}_{2} \mathrm{O}_{5}\right)(380 \mathrm{ppm})$, potasium $\left(\mathrm{K}_{2} \mathrm{O}\right)(520 \mathrm{ppm}), \mathrm{Fe}(5 \mathrm{ppm}), \mathrm{Cu}(2 \mathrm{ppm}), \mathrm{Zn}(2 \mathrm{ppm}), \mathrm{Mn}(2 \mathrm{ppm})$ in 1000 liter water per hectare sprayed at first week of May, third week of June and July). The concentration of some macro and micro elements in flower bud and in leaves, also productivity ( $\mathrm{g} / \mathrm{shoot}$ sectional area) mean nut weight, fresh weight of nut per cm2 branch cross sectional area, blanks nuts $\%$, non-split nut $\%$, new shoot growth length after cessation of growth and remained flower bud (\%) at the next spring were recorded for the different treatments. The results showed that boron and zinc concentration increased in the bud of sprayed trees in compare to control. Application of nutritional solution decreased the flower bud abscission, also resulted in increased vegetative growth, nut weight, and productivity of trees. In conclusion, spraying of fertilizers in the suitable time to the pistachio trees might be a useful method in decreasing flower bud abscission and mitigating the alternate bearing.
\end{abstract}

Key words: Flower bud retention, Boron, Zinc, Nitrogen, Phosphorus, Potassium

\section{Introduction}

Pistachio cultivars are highly alternate bearer tree. In literature many articles have been written about alternate bearing and foliar application of minerals on pistachio trees (Crane \& Nelson, 1971 and 1972; Roussos et al., 2003; Patrick et al., 1995; Uriu \& Crane, 1977; Weinbaum et al., 1994; Swietlik \& Faust, 1984; Adams 1996; Ferguson, 2003; Durzaii, 1996). Pistachio yields vary 3 to 5 fold between heavy cropping ('on') and subsequent light cropping ('off') years (Johnson and Weinbaum, 1987).

In several fruit trees it has been reported that even foliar spraying of micro and macro-elements has improved productivity. Harley et al., (1949) suggested that current growth of apple tree depended as much on tree nutrient reserves as on current nutrient uptake and the importance of nutrient reserves increases as trees grow older. Nyomora et al. (1997) mentioned that fertilizer application affects fruit set, nut quality and quantity, specially localized $B$ is necessary in the reproductive processes of many trees. Research with foliar application of nutrient on almond showed increasing fruit set and improved efficiency of fertilizer uses (Brown \& Uriu, 1996; Nyomora et al., 1997). Amount of fruit set depends on several factors related to flowering itself, concentration of minerals and environ- mental conditions such as temperature, relative humidity, rain, wind, etc. The majority of the commercial pistachio production is located in arid or semi-arid regions where the trees are frequently affected by water stress. Nyomora (1995) pointed out that boron deficiency generates less viability and germination of pollen grains and a reduction in tube growth. The applied B can correct current B deficiencies and also supply B to future developing flowers and fruit tissues. According to Viveros (1996) zinc and boron deficiencies cause anomalous almond fruit growing and promote fruit abscission thus reducing yields. According to Sotomayor (1997) fruit set is crucial in almond trees (Prunus dulcis) and it has been proven that micro-nutrients zinc and especially boron have a significant impact on fruit set, as well as on fruit let abscission.

According to Brown et al., (1995) boron spraying with $750 \mathrm{mg} /$ liter in the late dormant stage of pistachio, increased pollen viability and germination rate, increased fruit set and yield, decreased blanking percentage and increased leaf B concentrations. Also Baninasab et al., (2007) believe that nitrogen application appears to be the promising option for controlling alternate bearing of pistachios. Optimal $\mathrm{K}$ nutrition is essential to maximize pistachio nut yields (Zeny et al., 2000). $\mathrm{K}$ is an essential mineral for production and quality (Soing, 1999). Brown (1995) mentioned that the soil 
moisture regime is one of the factors affecting the potassium release or fixation, so in summer, $\mathrm{K}$ availability is reduced in the production areas. Then the foliar fertilization could be a solution to this problem. $\mathrm{K}$ is easily adsorbed and distributed trough leaf tissues.

To ensure optimal growth and productivity, an adequate amount of mineral nutrients should be applied to pistachio trees. Indeed pistachio is an old and important crop in Iran, especially in Khorasan which wild forests are distributed throughout most parts of this province. For that reason there is insignificant information on effects of foliar fertilizers on nut quality and biennial bearing. Therefore the objective of this study were to evaluate the effect of foliar application of zinc, boron, nitrogen, phosphorous and potassium on flower bud retention, nutrient concentration in leaves, shoot growth, nut quality, and total yields with the "Badamy sefid" the most important pistachio cultivar in Khorasan, Iran.

\section{Materials and methods}

The trial was performed during the 2007-2008 growing season at a commercial pistachio orchard at the Fayzabad, Khorasan Razavi province of Iran, (Latitude 39.295, Longitude 22.385) which covers an appropriate area for pistachio cultivation. The soil in this area is classified as loam with a $\mathrm{pH}$ of 8.2 , and contained 5.6 and $5.2 \mathrm{mg} / 100 \mathrm{~g}$ soil of plant-available $\mathrm{P}$ and $\mathrm{K}$, respectively. The soil was ploughed and treated with herbicides. "Badamy sefid" cultivar which are a widely cultivated in Khorasan, were planted in 1991, $3 \mathrm{~m}$ apart in rows that were $6 \mathrm{~m}$ apart. Trees were treated four times: 1). Just before anthesis with boric acid at $0.2 \%$, and Zinc at $4.5 \%, 2$ ). First week of May, 3), Third week of June 4), Third week of June) with nutritional solution combined of $400 \mathrm{ppm}$ Nitrogen, $380 \mathrm{ppm}$ phosphorus $\left(\mathrm{P}_{2} \mathrm{O}_{5}\right), 520$ ppm Potasium $\left(\mathrm{K}_{2} \mathrm{O}\right), 5$ ppm Fe, 2 ppm $\mathrm{Cu}, 2$ ppm Zn, and 2 ppm Mn. Volk $2 \%$ was used as a wetting agent. According to Banynasab et al., (2007) the first week of May, and third week of June and July were considered as flower bud initiation, beginning and middle of filling kernel respectively. The treatments replicated in three blocks, each comprising 10 trees, of which trees no. 1 and 10 were used as guard plants. Guard rows also surrounded the trial. On the basis of soil analysis, the orchard was fertilized with $50 \mathrm{~kg}$ of $\mathrm{N}$ ha-1 and $35 \mathrm{~kg} \mathrm{P}$ ha-1, before cultivation. Also $25 \mathrm{~kg}$ of $\mathrm{N}$ ha-1 were supplied with irrigation (every 24 days) during the growth season.

Weather data (precipitation, average, maximum and minimum temperatures) obtained from three stations around the experimental site. In August, during the later stages of fruit development, the mean temperature was $18.8^{\circ} \mathrm{C}$ and $20.8{ }^{\circ} \mathrm{C}$ for the years 2007 and 2008 , respectively, whereas the precipitation was 12,56 and $2 \mathrm{~mm}$, respectively. Fruits were harvested when visually estimated to be fully ripe (30 August 2007 and 11 September 2008).

Weight of nut per shoot cross sectional area, fresh and dry weight of nuts at harvest time, blankness (\%), non dehisced nuts $(\%)$ and new shoot growth length after cessation of growth were recorded. Flower bud were collected in late swelling stage (3 days after spraying) and leaf samples were collected randomly from non bearing shoots around the trees at mid July and analyzed for some macro and micro elements concentration. At the next spring bud retention (\%), was measured.

\section{Results and discussion}

Analysis of variance indicates that the $\mathrm{N}$ content of bud is higher than control treatment. B and $\mathrm{Zn}$ concentrations in female bud of sprayed trees were higher in compare to control. Hanson et al. (1985), Shrestha (1987) and Hanson (1991) pointed out that a momentary correction of a B level in flower tissues had a favorable effect on pollen tube growth stimulation by a localized effect. Results of the experiments done by Brown (1994) indicate that, there is a specific requirement for $\mathrm{B}$ in the developing flower. He believes that timing of foliar B spray is critical. Late dormant sprays (just prior to bud swell through to $20 \%$ bud break), are the most effective, later sprays effectively increase tissue B but may not enhance current year fruit yield or quality. In opposite of the above mentioned results, Silva \& Rodriguez, (1995) call the attention, that boron may have a normal foliar level but is insufficient in meristematic and flower tissues, but according to Viveros (1986), zinc and boron deficiencies cause anomalous almond fruit growing and promote fruit abscission, thus reducing yields.

The concentration of mineral nutrients in flower buds and leaves are depicted in Figures 1 and 2. Changes in flower bud concentration during the period of improving to fruit let are larger for $\mathrm{N}, \mathrm{P}$ and $\mathrm{Fe}$ than for other nutrients same as $\mathrm{Mn}$. The amount of $\mathrm{Na}$ concentrations did not show variability in the case of flower bud, whereas the concentration of other elements show some changes, which means, as the flower improves to fruit let, the concentration of some elements also improved.

Childers (1977); Micke (1996); Upadhayay \& Ananda (1991) and Dzhenena (1989) mentioned that, in the case of almond the general trend of $\mathrm{N}$ concentration at leaves is a decrease with time during the year and leaf $\mathrm{P}$ concentrations show more fluctuations than in the case of $\mathrm{N}$. Leaf $\mathrm{K}$ concentration tends to decrease somewhat with time, although no significant differences were found. However it is in the opposite whit our results but it seems that in the case of fruit set process and improving flower bud to fruit let, which the leave surfaces and photosynthesis process are not complete, the nutrients moves from other part of the tree to the growth points. On the other hand they believe that the maximum leaf concentration of $\mathrm{N}$ was found in full bloom stage period that corresponds to maximal vegetative growth. Tromp (1983) mentioned that, at bud break in spring, when root activity is still minimal, much of the minerals come from the supply stored in stems and roots. 

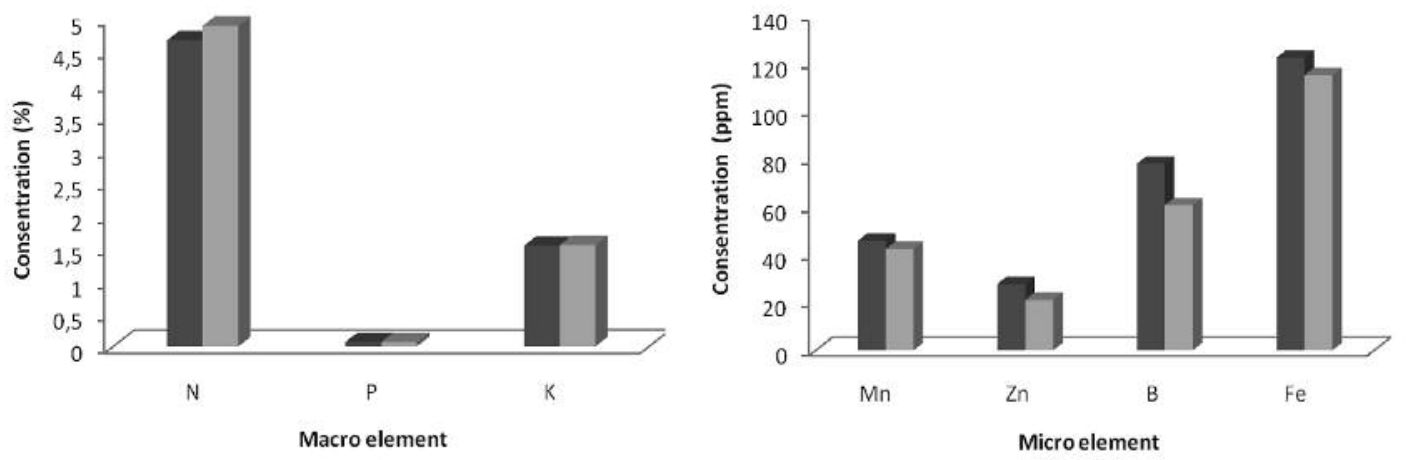

Figure 1. Consentration of nurtetional elements of female buds. Black and gray columns stand to sprayed and control trees respectively
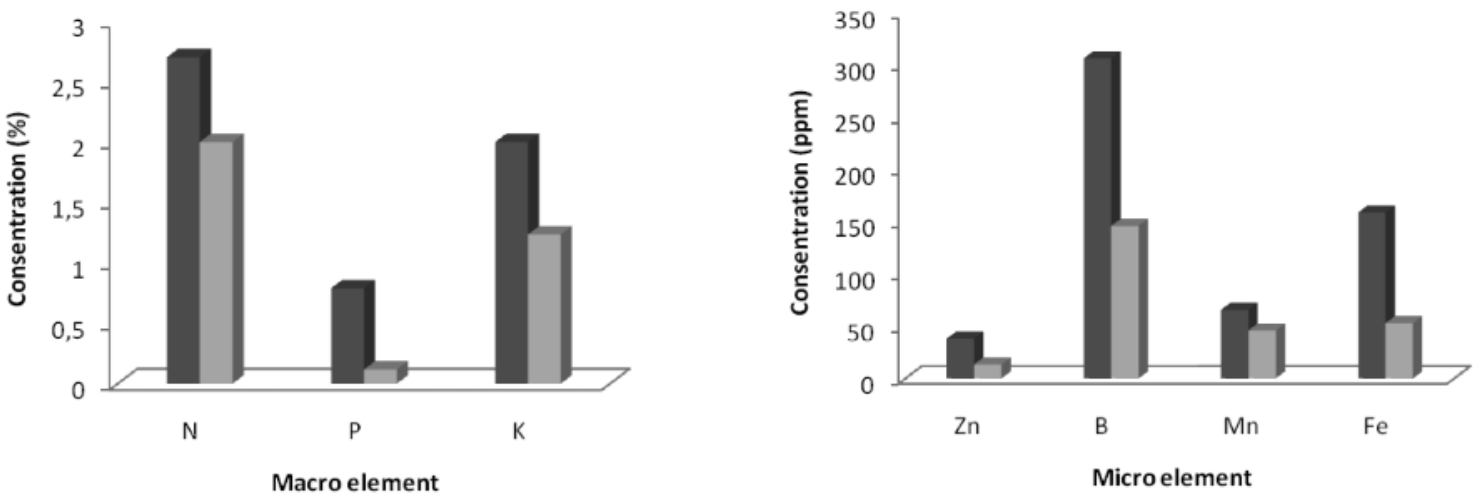

Figure 2. Consentration of nurtetional elements in pistachio leavs. Black and gray columns stand to sprayed and control trees respectively

In this case based on the $\mathrm{N}$ concentration in leaves during these stages, supplying $\mathrm{N}$-fertilizer for completing fruit set process is recommended.

In "Badamy sefid" pistachio trees which sprayed at bud swelling stage with boric acid at $0.2 \%$, and Zinc at $4.5 \%$, and above mentioned solution, $\mathrm{Zn}$ and $\mathrm{B}$ concentration in the leaves were 3 and 2 time higher compared with a non sprayed control. A similar pattern for Fe and P concentration changes was found in the leaves of sprayed tree in compare to control (Figure 2).

Foliar spraying resulted to a higher $\left(354 \mathrm{~g} / \mathrm{cm}^{2}\right)$ fresh weight of nut per unit of branch cross sectional area in compare with control $\left(170.4 \mathrm{~g} / \mathrm{cm}^{2}\right)$. Result of 2009 show that the fresh weight of nut per branch cross sectional area unit was higher than control (Figure 3). It has been determined that in several fruit crops low levels of boron can restrict fruit set rate, reducing fruit development and diminishing marketable fruit production. In sour cherry, prune and pear trees foliar boron sprays have been successful for improving yields (Hanson, 1991; Hanson et al., 1985). In agreeing with the result obtained by Silva \& Rodríguez (1995) and Nyomora et al (1997) which they believe, B and $\mathrm{Zn}$ foliar fertilization in almond has mainly a localized effect in the flower and achieves better fruit set. $\mathrm{N}$ fertilization increased the average single fruit weight both by extending the fruit development period and by increasing fruit growth rate and

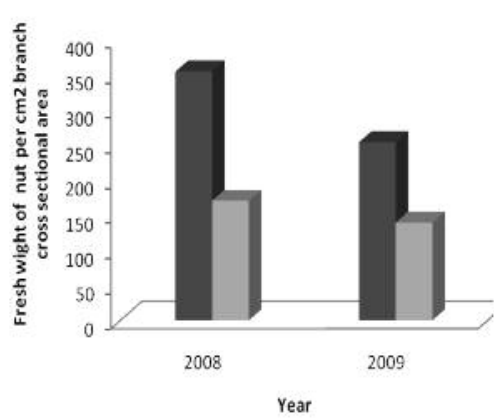

Year

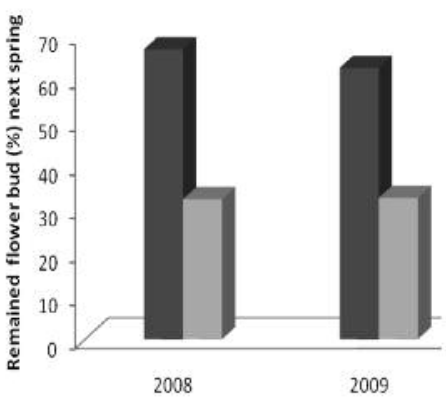

Year

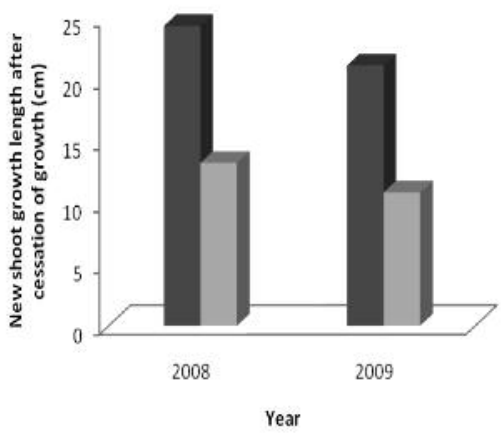

Year

Figure 3. Fresh weight of nut per $\mathrm{cm}^{2}$ branch cross sectional area, remained flower bud (\%) next spring and new shoots growth length after cessation of growth (cm). Black and gray columns in graph stand to sprayed and control trees respectively 
the increasing rates were $28.2 \%$ (fresh weight) and $19.4 \%$ (dry weight) compared with the unsprayed (controls). Optimal potassium nutrition is essential to maximize pistachio nut yields (Zeny et al, 2000). K is an essential mineral for production and quality (Soing, 1999).

It has been observed that, in blank nuts, the shell does not split, indicating the involvement of the seed in shell dehiscence. The extent to which blanks occur varies upon cultivar and rootstock and year to year. Both blanks nuts and non-split nut showed a simultaneous positive effect from increased fertilizer. By contrast, a negative relationship was found for new shoot growth length after cessation of growth and remained flower bud next spring in pistachio, which was explained as a result of competition (Figure 4).

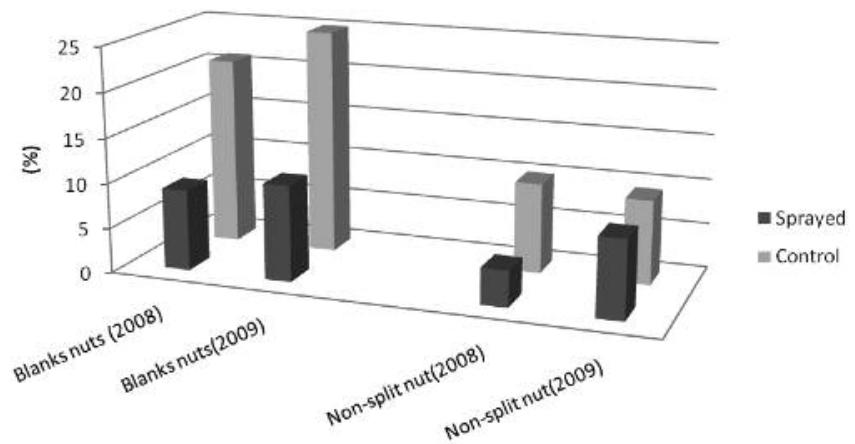

Figure 4. Blankness (\%) and non dehisced nuts (\%) in sprayed and control pistachio trees

\section{References}

Adams, G.P. (1996): The foliar approach to nutrition of pistachio. Pistachio production, 1-31.

Baninasab, B. 'Rahemi, M. \& Javanshah, A. (2007): Effects of Time of Foliar Application of Nitrogen and its Concentrations on the Flower Bud Retention in Pistachio Trees International Journal of Soil Science, 2: 40-47.

Brown, P. \& Uriu, K., (1996): Nutrition deficiencies and toxicities: diagnosing and correcting imbalances. In: Almond Production Manual. Univ. California, Div. Agric. Nat. Res. Publ. 3364, pp 179-188.

Brown, P. H., Ferguson, L. \& Picchioni, G. (1995): Boron boosts pistachio yields. Fluid Journal, 1-3.

Childers, N. (1977): Modern fruit science. Horticultural publications, 234-236.

Crane, J.C. \& Nelson, M.M. (1971): The unusual mechanism of alternate bearing in pistachio. HortScience, 6: 489-490.

Crane, J.C. \& M.M. Nelson, (1972): Effect of crop load, girdling and auxin application on alternate bearing of the pistachio. J. Am. Soc. Hortic. Sci., 97: 337-339.

Durzaii, D.J., (1996): Nitrogen reallocation during female bud abscission in alternate bearing of pistachio. Adv. Hortic. Sci., 10: 219-225.

Dzhenena, A. (1989): Relationships between leaf chemical composition and yield in almond. Hort. Abstracts, 62: 642.

Ferguson, L. (2003): Pistachio production year book. Davis University

Ferguson, L. (1986): Effect of foliar urea applications on leaf nitrogen content and bud retention in pistachios. Calif Pistachio Indus., Ann. Report, pp: 94-95.
Hanson, E., Chaplin, M. \& Breen, P. (1985): Movement of foliar applied boron out of leaves and accumulation in flower buds and flower parts of 'Italian' prune. HortScience, 20: 747-748.

Harley, C.P., Moon, H.H. \& Regeimbal, L.O. (1949): A study of correlation between growth and certain nutrient reserves in young apple trees. Proc. Am. Soc. Hort. Sci., 53: 1-5.

Johnson R.S. \& Weinbaum S.A. (1987): Variation in tree size, yield, cropping efficiency, and alternate bearing among 'Kerman' pistachio trees. J. Am. Soc. Hort, Sci., 112: 942-945.

Lovatt, C.J. \& Ferguson, L. (1994): Using foliar applications of urea combined with 6-benzyladenine to decrease pistachio floral bud abscission in an on-year to increase yield the next year. Calif Pistachio Indus., Aim. Report, pp: 155-158.

Micke, W., (1996): Almond production manual. University of California. Publ., 289.

Nyomora, M., Brown, P. \& Freeman, M. (1997): Fall foliar applied boron increases tissue boron concentration and nut set of almond. J. Amer. Soc. Hort. Sci., 122 (3): 405-410.

Patrick, H. Brown, Steven, A. Weinbaum, \& Picchioni, Geno, A. (1995): Alternate bearing influences annual nutrient consumption and the total nutrient content of mature pistachio trees. Trees 9: 158-164.

Porlingis, I.C., (1974): Flower bud abscission in pistachio, as related to fruit development and other factors. J. Am. Soc. Hortic. Sci., 99: 121-125.

Roussos, P.A., Pontikis, C.A. \& Zoti, M.A. (2003): The role of free polyamines in the alternate-bearing of pistachio (Pistacia vera cv. Pontikis). Trees, 18: 61-69.

Shrestha, G., Thompson, M. \& Righetti, T., (1987): Foliar applied B increases fruit set in hazelnut. J. Amer. Soc. Hort. Sci., 112: 416-421.

Silva, H. \& Rodríguez, J., (1995): Fertilización de plantas frutales Ed. Univ. Católica, Santiago de Chile, 520 pp.

Sotomayor, C. (1997): Evaluación de diferentes modalidades de polinización en almendro.Cienc. Invest. Agrar., 24 (1): 7-11.

Swietlik, D. (1999): Zinc nutrition in horticultural crops. Hort. Rev., 23: 109-178.

Swietlik, D. \& Faust, M. (1984): Foliar nutrition of fruit crops. Hort. Rev., 6: 287-338.

Tromp, J. (1983): Nutrient reserves in roots of fruit trees, in particular carbohydrates and nitrogen. Plant Soil, 71: 401-413.

Upadhayay, S.K. \& Ananda, S.A. (1991): Effect of rootstock and scion cultivars on the macro-nutrient contents in almond leaves. Hort. Abstracts, 62: 1155. 317.

Uriu, K. \& Crane, J.C. (1977): Mineral element changes in pistachio leaves. J. Am. Soc. Hort. Sci., 102: 155-158

Viveros, M., (1996): Minor nutrients essential for almonds. Amer. Fruit Grow., 116 (2): 39.

Weinbaum, S.A., Picchioni, G.A., Muraoka, T.T. \& Ferguson, L., Brown, P.H. (1994): Fertilizer nitrogen and boron uptake, storage and allocation vary during the alternate bearing cycle in Pistachio trees. J. Am. Soc. Hort. Sci. 119: 24-31

Weinbaum, S.A., GA. Picchioni, T.T. Muraoka, L. Ferguson \& Brown, P.H. (1994): Fertilizer nitrogen and boron uptake, storage and allocation vary during the alternate-bearing in pistachio trees. J. Am. Soc. Hortic. Sci., 119: 24-31.

Zeny, D., Brown, H. \& Rosecrance, R. (2000): The Effect of Alternait Pistachio. Calif.Univ. Department of pomology. 